\title{
All Things Collected
}

\author{
Hülya Yağcıoğlu
}

My co-editor, Ileana Baird, and I started thinking about this book in the summer of 2017, right after the conclusion of our seminar, "Things and Their Global Networks: Thing Theory, 15 Years Later," organized at the Annual Meeting of the American Comparative Literature Association in Utrecht, the Netherlands. The goal of this three-day seminar was to investigate the relationship between human and nonhuman subjects in different historical and cultural contexts. The engaging discussions we had with the panelists during the conference inspired us to dwell more on material culture, specifically the material culture of the Arabian Peninsula, and to examine how local objects have helped define what we call "Arabia" and "Arabian" throughout the ages. This decision stemmed not only from our love for the local culture-both my co-editor and I live and work in Abu Dhabi, U.A.E.- - but also from our interest in investigating the cultural significance of Arabia, a place strategically situated at the junction of three continents, at the crossroads of human civilizations.

As Bill Brown posits, we may find in things "not just the physical determinants of our imaginative life but also the congealed facts and fantasies of a culture."1 Therefore, the main focus of this book is to examine the role played by objects in creating regional and local identities. Not only do local objects, such as pearls, frankincense, and al-Sadu weaving, create a distinctive "Arabian" identity throughout history; the Western world's fictional encounters with the things of Arabia have also led to often stereotyped and inaccurate representations of the place. Archeological, historical, ethnographical, anthropological, literary, and art-related

1 Bill Brown, A Sense of Things: The Object Matter of American Literature (Chicago: University of Chicago Press, 2003), 4. readings offered by our contributors demonstrate how objects are at the center of a community's representation of its own cultural place and of the way this image is assembled globally, in the collective imaginary. The multidisciplinary nature of this collection allows, thus, for an exploration of Arabia's things from a variety of perspectives that can provide, we hope, a better understanding of its unique contribution to the world heritage.

A recent archeological exhibition from the region, Roads of Arabia: The Archeological Treasures of Saudi Arabia, has been another pivotal moment that triggered our interest in the material culture of the region. First inaugurated at the Louvre $\mathrm{Mu}-$ seum in Paris in 2010, it has since travelled across the world and has been exhibited in fifteen museums, attracting more than five million visitors so far. Covering a wide historical period, the exhibition starts from prehistoric Arabia and demonstrates the presence of ancient human settlements in the region dating as far back as 7,000 B.C. The maritime and caravan routes of the Arabian Peninsula, as well as its pilgrimage roads and modern highways are the other focal points of this exhibition. The hundreds of artifacts displayed include Neolithic steles and statues, wall paintings, vases, jewelry, tombstones, keys to Ka'ba, maps, and Qur'anic inscriptions. Thus, this exhibition has helped change common perceptions about the area, revealing its rich historical and cultural heritage. As Jean-Luc Martinez, the President-Director of Musée du Louvre, explains, Roads of Arabia has demonstrated that the Peninsula "has always been a fertile ground for human encounters and artistic expressions." ${ }^{2}$ The unexplored past of this region is

\footnotetext{
2 Qtd. in Souraya Noujaim, "From Past to Future, Now and Always, an Eternal Dream," in Roads of Arabia: Archeological Treasures of Saudi Arabia, ed. Souraya Noujaim and
} 
laid bare in the displayed objects, which encapsulate the cultural, economic, and religious significance of "Arabia" for the travelers, pilgrims, and merchants who crossed it since ancient times. After being showcased in many prominent museums in Europe, North America, and Asia, the exhibition finally arrived at Louvre Abu Dhabi in 2018, where it was enriched by many archeological findings from the U.A.E. According to Manuel Rabaté, the director of Louvre Abu Dhabi, the exhibition "allow[ed] the international public to cultivate a better-informed view of the present-day realities of a region of crucial global importance."3 Moreover, as Islamic scholar Jacques Berque points out, it revealed the "symbolic quality of the Arab East, which is related to the close involvement of facts and values, the upsurge of the new from the old, and the compromise between the one and the other." $^{4}$

The discovery of oil in many Arab countries in the second part of the twentieth century has given way to drastic economic and social transformations, determining the current position of the region in the international arena. Immersed in the rich Emirati culture, my co-editor and I became interested in examining the relationship between various local objects and Emirati national identity, in delving into "the role of material culture in creating and shaping a shared consciousness and collective identity" ${ }^{5}$ after the oil boom. One of the largest oil-producing countries worldwide, with three million barrels of oil per day, ${ }^{6}$ the United

Noëmi Daucé (Beirut: Louvre Abu Dhabi/Art Book Magazine Éditions, 2019), 15

3 Ibid., 17.

4 Jacques Berque, The Arabs: Their History and Future, trans. Jean Stewart (London: Faber \& Faber, 1964), qtd. in Noujaim, "From Past to Future," 21.

5 Geneviève Zubrzycki, "Introduction. Matter and Meaning: A Cultural Sociology of Nationalism," in National Matters: Materiality, Culture, and Nationalism, ed. Geneviève Zubrzycki (Stanford: Stanford University Press, 2017), 5 .

6 "Our History," Abu Dhabi National Oil Company, accessed April 5, 2019, https://www.adnoc.ae/en/about-us/our-hi tory.
Arab Emirates has enjoyed a robust economy, high standard of living, and unprecedented prosperity since the discovery of oil in 1958. However, the wealth coming from the oil revenue has also changed the nation's relationship with its material objects, so cherished in its pre-oil times. As opposed to older generations who depended on fishing and pearl diving, the new generations of Emiratis live in a culture of conspicuous consumption. The country boasts a rapid pace of transformation from a desert to a top-class nation of superlatives due to its unparalleled entrepreneurial spirit: it houses today the world's tallest building, the largest man-made island, the biggest shopping mall, and the only seven-star hotel in the world. The profusion of consumer products and the desire to acquire them has led to a sort of commodity fetishism whereby things are no longer valued for what they represent but for the symbolic power they invest their owner with. As Georg Lukács explains, the inclusion of the capital in the social life engenders an objectification of social relations which often obscures the relations between the subject and the object. ${ }^{7}$ This is also in line with Guy Debord's vision of modern society as a society of the spectacle, based on a monopoly of appearances, as commodification dominates the entire human experience. ${ }^{8}$ In such a view, social relations describe an existence in which "having" resonates with "being," ultimately giving way to a new relation with material objects.

This vested interest in objects as commodities has been accompanied in the region by a growing interest in collecting culturally significant objects both in museums and private collections. In Collecting in a Consumer Society, Russell W. Belk states that "collecting things and displaying things should flourish among individuals and museums Georg Lukács, History and Class Consciousness: Studies in Marxist Dialectics, trans. Rodney Livingstone (Cambridge, MA: MIT Press, 1967), 92. Nicholson-Smith (New York: Zone Books, 1995), 36. 
in a consumer culture."9 Indeed, as Karen Exell posits, the more exposed the region is to the outside world, the more private collections have proliferated due to the need to safeguard traditions through a preservation of their material expressions. ${ }^{10}$ Discussing the recent collecting practices in the U.A.E., Emily Doherty interrogates, however, whether the younger Emiratis, who are not formally educated in the arts, could appreciate art objects when they compete with commodities such as "Gucci handbags, Porsches, Apple IPods," and whether they could be motivated to invest in art galleries rather than malls. ${ }^{11}$ She suggests that "the joy of ownership," that is, the delight brought by material possessions, might be the answer. ${ }^{12}$ This indicates the displacement of an object from its use value to its symbolic value, as it is transformed from an object that is consumed to an object that is collected. For Walter Benjamin, a collected object is "divested of its function and relocated from its commodity scene" to be re-appropriated in a more intimate, subjective realm by the collector. ${ }^{13}$ In other words, collecting objects can be a way for individuals to relate "to their society and its past in order to construct their own personalities."14

Among the many events in the region, Lest We Forget exhibitions in the U.A.E. have had a special

Russell W. Belk, Collecting in a Consumer Society (London: Routledge, 1995), 139.

10 Karen Exell, "Introduction: Questions of Globalization, Modernity and the Museum in the Arabian Peninsula," in Modernity and the Museum in the Arabian Peninsula, ed. Karen Exell (Oxon: Routledge, 2016), 12.

11 Emily Doherty, "The Ecstasy of Property: Collecting in the United Arab Emirates," in Archives, Museums and Collecting Practices in the Modern Arab World, ed. Sonja Mejcher-Atassi and John Pedro Schwartz (Farnham: Routledge, 2012), 193 .

12 Ibid.

13 Walter Benjamin, "Unpacking My Library: A Talk about Book Collecting," in Illuminations: Essays and Reflections, ed. Hannah Arendt and trans. Harry Zohn (New York: Schocken Press, 1969), 60.

14 Susan M. Pearce, On Collecting: An Investigation into Collecting in the European Tradition (London: Routledge, 1995), 159. place as they showcased for the first time personal objects belonging to local Emiratis. The first exhibition, Lest We Forget: Structures of Memory (2014), focused on the history of architectural and urban developments of the seven Emirates. The second edition of the exhibition, Lest We Forget: Emirati Family Photographs 1950-1999 (2015), displayed private family photographs provided by Emiratis, while the third edition, Lest We Forget: Emirati Adornment: Tangible \& Intangible (2017), presented items of clothing, jewelry, and weapons, as well as perfume and cosmetics - all contributed by the public. For Michele Bambling, the creative director of the exhibition, the purpose of this initiative was "to really develop a history of vernacular Emirati memory, not just of Emiratis, but of people who have lived and contributed to the Emirates."15 The privately-owned everyday objects displayed in the exhibition are part of the tangible and intangible heritage of the nation. As opposed to the structured museums owned by the government, these exhibitions focus on aspects of individuals' private lives, displaying objects that were once integral parts of their daily routines. As such, these objects represent a more personal way of recording the past as they lie at the center of the local people's spiritual world, highlighting how a people's identity and culture is embedded within objects of everyday life.

Material objects have also come to represent and preserve the past in their capacity of bearers of a people's cultural identity over time. Besides this burgeoning interest in collecting in the region, Pamela Erskine-Loftus calls attention to the "heritage revivalism" apparent in the many heritage museums that display ethnographic objects in restored buildings of local architecture. ${ }^{16}$ A tendency

\footnotetext{
15 Qtd. in Nick Leech, "New Lest We Forget Exhibit Tells U.A.E.'s History with Tales and Heirlooms," The National, February 2, 2017, https://www.thenational.ae/uae/ new-lest-we-forget-exhibit-tells-uae-s-history-withtales-and-heirlooms-1.47002 ?videoId=5598744747001.

16 Pamela Erskine-Loftus, "Introduction: Common Purpose and Uncommon Outcomes: The Cultural
} 
toward building national heritage museums rather than world heritage museums coincides with an increasing political and national awareness of the need to assert the new state's distinctive identity. ${ }^{17}$ In the U.A.E., state authorities have invested heavily in museums such as the Al Ain National Museum, the National Museum of Ras al Khaimah, and the Zayed National Museum in Abu Dhabi (currently in progress), as well as in heritage villages, such as the ones in Abu Dhabi, Dubai, Fujairah, and Ras al Khaimah. The Zayed National Museum, in particular, is an ambitious project designed by the starchitect Norman Foster in the form of a falcon's feathers, the falcon being an iconic symbol of the U.A.E. It aims at bringing together "contemporary form with elements of traditional Arabic design and hospitality to create a museum that is sustainable, welcoming and culturally of its place."18 As Geneviève Zubrzycki points out, the built environment and the landscape are as important as the material artifacts in a museum in creating "historical narratives and national myths" as they render "otherwise distant and abstract discourses close" to the social actors who inhabit or witness them. ${ }^{19}$ Such museums, as well as important annual heritage festivals, such as Qasr Al Hosn Festival and Sheikh Zayed Heritage Festival, aim at preserving the local values of the pre-oil past and serve to counterbalance the impact of globalization on the country. The objects displayed are both symbols of a collective history and of nationbuilding, as "tribal affiliation and solidarity is slowly being replaced by national solidarity." 20 This

Transferability of Museums," in Reimagining Museums: Practice in the Arabian Peninsula, ed. Pamela ErskineLoftus (Edinburgh: MuseumsEtc., 2014), 20.

Pamela Erskine-Loftus, "Introduction: Ultra-Modern Traditional Collecting," in Museums and the Material World: Collecting the Arabian Peninsula, ed. Pamela Erskine-Loftus (Edinburgh and Boston: Museums Etc., 2014), 42-43.

18 Exell, "Introduction: Questions of Globalization," 15.

19 Zubrzycki, "Introduction. Matter and Meaning," 5.

20 Erskine-Loftus, "Introduction: Ultra-Modern Traditional Collecting," 38 . "national sensorium," as Zubrzycki describes it, helps generate "sentiments of national belonging and resonant emotional attachments to what is otherwise merely a distant imagined community."21

As Erskine-Loftus indicates, the Gulf states are currently experiencing the most explosive per capita museum building boom in history. ${ }^{22}$ Besides the recent development of several important museums in the region, ${ }^{23} \mathrm{Abu}$ Dhabi, the capital city and the wealthiest state of the U.A.E., has built a museum district dedicated to arts and culture in Saadiyat Island (The Isle of Happiness) that hosts important international museums, such as the Louvre Abu Dhabi and Guggenheim Abu Dhabi. In museums, however, history is represented as a transmission of the "spoils" of ages to the present, divorced from the environment in which these artifacts were produced. The museum is a space symbolizing modernity and reflects the Western culture of the nineteenth century, with its organizing impulse to accumulate time in an immobile space. ${ }^{24}$ Therefore, the regional proliferation of international museums based on Western models might seem, at first blush, controversial since the museum is a truly Western invention. The Abu Dhabi versions of the Louvre and Guggenheim, however, are not attempts at duplicating the Western museums; instead, as explained by the French Culture Minister Gilles de Robien, they are "part of a wish to find a dialogue between East and West."25

21 Zubrzycki, "Introduction. Matter and Meaning," 5 .

22 Erskine-Loftus, Museums and the Material World, back cover.

23 The increasing interest in the acquisition and display of local artifacts is evidenced by the recent development of several important museums in the region, such as the Museum of the Islamic Art and the National Museum of Qatar, Mathaf: The Arab Museum of Modern Art in Doha, King Abdul Aziz Center for World Culture in Dhahran, Saudi Arabia and The National Museum of the Sultanate of Oman. Michel Foucault, "Of Other Spaces," trans. Jay Miskowiec, Diacritics 16, no. 1 (Spring 1986): 26. and Identity in Abu Dhabi," in Cultural Heritage in the 
The Louvre Abu Dhabi's claim of universality and cross-cultural dialogue is also evident in the statement posted on the museum website, which mentions a focus "on what unites us: the stories of human creativity that transcend individual cultures and civilizations, times or places." 26 One reason underlying such an investment is, perhaps, to place Abu Dhabi on the cultural and touristic world map as a cosmopolitan center in order to attract tourism revenues and diversify its oil-dependent economy. Another reason could be the emirate's aspiration to educate its young generation in the value of understanding other cultures and developing a global mindset. The main reason, however, is probably maintaining cultural legitimacy through cultural capital. Sarina Wakefield argues that, with these franchise museums, Abu Dhabi will "place itself on the map of globally significant cities by promoting itself as a cosmopolitan center within the Arabian Gulf."27 For Exell, these museums signify "an attempt at shifting global cultural centers, not just within the Arab world but in relation to the West, and demonstrating a fluent understanding of Western cultural values."28 Providing an interesting slant to this local vs. global dichotomy, the franchise museums in Abu Dhabi help the country assert its global influence, as well as laying the foundation for a dynamic cultural life in the region.

Just like a museum, this volume brings together different objects which have historically and imaginatively represented Arabia. While the countries of the Arabian Peninsula have started to assert their own cultural identities after the emergence

Arabian Peninsula: Debates, Discourses and Practices, ed. Karen Exell and Trinidad Rico (Farnham: Ashgate, 2014), 108.

"Our Story," Louvre Abu Dhabi, accessed April 10, 2019, https://www.louvreabudhabi.ae/.

Wakefield, "Heritage, Cosmopolitanism and Identity in Abu Dhabi," 100.

Exell, "Introduction: Questions of Globalization," 2. of the modern nation states, we can still recuperate an "Arabian" identity that is the product of common experiences, traditions, fictions, and material culture. In her chapter, Victoria Penziner Hightower considers the pearl as an iconic signifier of Arabia and its most important object of regional and global trade in the past. Other important historical symbols associated to an Arabian identity, the frankincense and the date palm, are studied by William Gerard Zimmerle and Eran Segal in their respective chapters in light of their economic, symbolic, and political power in the life of the peoples of the peninsula. On the other hand, Yannis Hadjinicolaou demonstrates how objects can act as substitutes for ideas, examining the visual renderings of the falcon as a symbol of political strength and sovereignty in the Gulf countries.

Other objects — used, traded, or displayed — are embeddedin personal stories, aswell asinsocialand cultural practices in the region. Joseph Donica examines keffiyeh, the traditional head covering worn by Arab men, as an important cultural symbol and identifier of Arabness. Rana Al-Ogayyal and Ceyda Oskay discuss how al Sadu, a type of traditional nomadic weaving popular in the Arabian Peninsula, evokes the idea of portable home and contains symbols that act as identity markers for the Bedouin tribes. Similarly, Marie-Claire Bakker and Kara McKeown explore the importance of ornaments and jewelry for Khalïjiwomen and their role in creating a sense of personal and communal identity. The power of objects to evoke the past and preserve it in the memory of local people is examined by two other contributors: James Redman, who interrogates the value of kirsh kitab, protective medallions inscribed with Qur'ānic texts, as mnemonic objects, and Chrysavgi Papagianni, who explores theimpact of oil on local processes of identity formation and preservation through the medium of film.

Finally, equally important in constructing a distinct "Arabian" identity throughout the ages, the things of the imagination, that is, things that conjure up Arabia in the Western imaginary through fictional narratives, are given due attention for their essential role in processes of identity 
formation and self-definition in the region. The chapters by Ileana Baird, Jennie MacDonald, and Holly Edwards look at how things representing "Arabia" in Orientalist literature, travel narratives, paintings, theater, and film have led to stereotypes and myths pervasive in our culture to this day, which have solidified Arabia's exoticism.

By placing the things of imagination side by side with the real things of Arabia, this volume acts as a museum of the mind: the objects it displays aim to illustrate, complicate, and dispel stereotypes about the region and reveal how the material culture of the area has been embedded in the construction of a local and global Arabian identity over time. This interplay of national, regional, and global identities blurs the subjectobject binary, calling attention to their mutually informing relationship. As we have tried to suggest in this volume, the objects studied here are not only silent partners in Arab people's lives but also active participants in the histories of the communities, nations, and cultures of the region at large. 